\title{
Sekosteroit bir hormon olarak D vitamini ve kanser ilişkisi*
}

As a secosteroid hormone vitamin $D$ and cancer relationship

İbrahim Duman', İsmail Ünii

'MSc, Mersin Üniversitesi Tıp Fakültesi, Tıbbi Farmakoloji Anabilim Dalı, https://orcid.org/0000-0002-3961-5702

iiDoç. Dr, Mersin Üniversitesi Tıp Fakültesi, Tıbbi Farmakoloji Anabilim Dalı, https://orcid.org/0000-0001-6442-4185

öz

Klasik olarak kalsiyum ve fosfat mekanizması üzerine olan etkilerinin yanı sıra antiproliferatif ve immünomodülatör gibi özellikleri de olan D vitamini aslında bir sekosteroit hormondur. Yakın dönemde yapılan çalışmalar, D vitamini eksikliğinin otoimmün ve kardiyovasküler hastalıkların yanı sıra kanser riskini de artırabildiğini göstermiştir. D vitamini eksikliği dünyada küresel bir salgın olarak bildirilmiştir. Buna ek olarak osteoporoz ve düşme kırıkları için de bir risk faktörü olarak tanımlanmıştır. Diyetle alınan ve deride güneş aracılığı ile sentezlenen D vitamininin, kandaki normal seviyelerinin sağlanması için doğru bilgi sahibi olmak çeşitli hastalıklardan ve kanserden korunmak açısından önemlidir. Bu nedenle öncelikle $D$ vitaminin sentezi, kandaki düzeyleri, günlük intiyaç, metabolizması ve reseptörlerinin durumu derlendi. Buna ek olarak D vitamininin iyi bilinen kemik mineralizasyonu dışındaki etkilerinden olan özellikle kanser gelişimi ile olan ilişkisine dair güncel bilgiler derlendi.

Anahtar Kelimeler: D vitamini, Sekosteroit, Kanser

\section{ABSTRACT}

In addition to its well known classical effect on calcium and phosphate metabolism vitamin D which is actually a secosteroid hormone also has antiproliferative and immunomodulatory properties. Recent studies have shown that vitamin D deficiency may increase autoimmune and cardiovascular diseases as well as cancer risk. Vitamin D deficiency has been reported as a global epidemic in the world. In addition it has been identified as a risk factor for osteoporosis and fall fractures. The right information to ensure normal levels of vitamin $D$ taken from the diet and synthesized by the sunlight is important for protecting against various diseases and cancer. Firstly, the synthesis, blood levels, the daily need, the metabolism and the status of the receptors of vitamin D have been presented. In addition, current information on the association of vitamin D with cancer developments that those outside the well-known bone mineralization, were particularly presented.

Keywords: Vitamin D, Secosteroid, Cancer

\footnotetext{
*Lokman Hekim Dergisi, 2019; 9 (1): 19-29

DOI: $10.31020 /$ mutftd.456806

e-ISSN: 1309-8004

Geliş Tarihi-Received: 3 Eylül 2018; Kabul Tarihi - Accepted: 3 Ekim 2018

iletişim - Correspondence Author: Ismail Ün <ismailun@mersin.edu.tr>
} 


\section{GíRiş}

Son zamanlarda $D$ vitamini birçok kanser türünün, oluşma riskini azaltmak için önerilmiştir. ${ }^{1-2} \mathrm{D}$ vitamini aslında bir sekosteroit hormondur ve en önemli rolü kalsiyum ve fosfat mekanizması üzerinedir. ${ }^{3}$ Bu temel fonksiyonunun yanında, D vitamini hücre büyümesi ve nöromüsküler fonksiyonları da düzenlemektedir. ${ }^{4}$ Buna ek olarak, çeşitli in vitro ve in vivo çalışmalar, D vitamini eksikliğinin kanser, otoimmün ve kardiyovasküler hastalık riskini artırabildiğini göstermiştir. ${ }^{4,5} \mathrm{D}$ vitamininin vitamin $\mathrm{D}_{2}$ (ergokalsiferol) ve vitamin $D_{3}$ (kolekalsiferol) olmak üzere iki önemli formu vardır. ${ }^{6,7}$ Yapılan çalışmalar kalsitriol $\left(1,25(\mathrm{OH})_{2} \mathrm{D}_{3}\right)$ ve analoglarının, D vitamini reseptörünün aracılığı ile insan kanser hücrelerinin çoğalmasını inhibe ettiğini göstermiştir. ${ }^{8} \mathrm{D}$ vitamini reseptörünün bugün otuzdan daha fazla dokuda bulunduğu gösterilmiştir. ${ }^{9-11}$

Son zamanlarda artan kanıtlar, D vitamininin ve reseptörünün jinekolojik kanserlerin gelişiminde önemli bir rol oynadığını göstermektedir. ${ }^{12}$ Endometriyal dokuda $D$ vitamini reseptör varlığının gösterilmesi, aynı zamanda kalsitriolün, kanser riskini ve prognozunu belirlemede rol oynayabilen birçok hücresel yolları regüle etmesi, D vitamininin endometriyum kanser etiyolojisinde rol oynayabileceğini işaret etmiştir. ${ }^{8}$ Yakın zamanda endometriyum kanser hücreleri üzerine paklitaksel ve karboplatinin etkisini araştıran bir çalışmada, $1,25(\mathrm{OH})_{2} \mathrm{D}_{3}{ }^{\prime}$ ün bu ajanlarının sitotoksik etkisine katkıda bulunabileceği de vurgulanmıştır. ${ }^{3}$

\section{Vitamini}

D vitamini, antiproliferatif ve immünomodülatör bir sekosteroit hormondur, en önemli fonksiyonu kalsiyum ve fosfat mekanizması üzerinedir. ${ }^{3}$ Kemik homeostazında önemli rolü olan liposolubl bir hormondur. D vitamini eksikliği dünyada küresel bir salgın olarak bildirilmiş ve osteoporoz ile düşmeye bağlı kırıkları için de bir risk faktörü olarak tanımlanmıştır. ${ }^{13}$

Ayrıca, D vitamini kadın üreme sisteminde de önemli bir rol oynamaktadır; bu görüşü destekler şekilde $D$ vitamini reseptörü over dokusunda, endometriyumda, fallop epitel hücrelerinde, desidua ve plasentada eksprese edildiği gösterilmiştir. ${ }^{4}$ Son yıllarda $D$ vitamini metabolizması ile endometriozis, uterin fibroidler ve polikistik over sendromu gibi bazı jinekolojik hastalıkların gelişimi arasında ki bağlantıyı ortaya koymak için bu alanda araştırmalara yönelme olmuştur. ${ }^{4}$

D vitamininin antikanserojen bir role sahip olduğu konusunda güçlü kanıtlar mevcuttur. ${ }^{14}$ Bir çok hücre çekirdeğinde ve dokuda $D$ vitamini öncüsünün aktif forma dönüştürülmesinden $D$ vitamini reseptörü ve $1 \alpha-$ hidroksilaz enzimi sorumludur. ${ }^{4} \mathrm{D}$ vitamini reseptörü bugün otuzdan daha fazla dokuda bulunmaktadır; endotel, düz kas, kalp kası, beyin, meme, prostat, kolon hücreleri, immün hücreler vb. ${ }^{9-11}$ Ayrıca, yapılan çalışmalar ve epidemiyolojik araştırmalarda; kolorektal, göğüs, yumurtalık, prostat ve diğer kanserlerin gelişimine karşı D vitaminin koruyucu rolünün olduğunu gösterilmiştir. ${ }^{4,15}$

\section{Vitamini Kaynakları ve Metabolizması}

İnsanlar için temel D vitamini kaynağı güneşe yeteri kadar maruziyettir. D vitamini hem diyet olarak alınabilmekte hem de endojen olarak vücutta yapılabilmektedir. D vitamininin, vitamin $D_{2}$ (ergokalsiferol) ve vitamin $D_{3}$ (kolekalsiferol) olmak üzere iki önemli formu vardır. Bitkilerde bulunan vitamin $D_{2}$ ve hayvan dokularında bulunan vitamin $D_{3}$, diyet ile dışarıdan süt, yoğurt, ekmek, balık yağı, zenginleştirilmiş besinler ya da besin takviyesi olarak alınabilmektedir. Diyetle alınan $\mathrm{D}$ vitamini hem vitamin $\mathrm{D}_{2}$ hem de vitamin $\mathrm{D}_{3}{ }^{\prime} \mathrm{ü}$ ifade etmektedir. ${ }^{6,7} \mathrm{D}$ vitamini kaynakları Tablo 1'de özet olarak verilmiştir.

Tablo 1. D vitamini kaynakları

\begin{tabular}{|l|l|}
\hline D vitamini kaynakları \\
\hline Güneş ışınları etkisiyle cilt & 7-dehidrokolesterol \\
\hline Yiyecekler & Bitkisel: Ergokalsiferol (Vitamin D2) \\
& Hayvansal: Kolekalsiferol (Vitamin D3) \\
\hline İlaçlar & Kalsitriol, alfakalsidiol, kalsipotiriol vb \\
\hline
\end{tabular}


Endojen olarak D vitamini sentezi; epidermisin güneş ışınlarındaki ultraviyole (UV) radyasyona (özellikle UVB radyasyonu) maruziyeti sonucunda, prekürsör olan 7-dehidrokolesterolün aktif olarak previtamin $D_{3}$ dönüştülmesiyle başlar. Previtamin $D_{3}$ karaciğere kan yolu ile taşınarak, burada 25-dehidroksivitamin $D^{\prime} y e$ hidroksillenir. Bu form kan yolu ile böbreğe gelerek, D vitaminin aktif formu olarak bilinen $1,25(\mathrm{OH})_{2} \mathrm{D}^{\prime}$ ye (kalsitriol) hidroksillenir. Aşırı güneş ışığına maruz kalınmasının vitamin D intoksikasyonuna neden olmadığı bildirilmiştir. ${ }^{7,16}$ Birçok insan için güneş ışınları (UVB) D vitamininin primer kaynağıdır. ${ }^{17}$ Güneş ışınlarına 20 dakika (290-315 nm dalga boyunda ultraviyole ışınları) maruz kalan yüz ve kol bölgesine ait deri, günlük 200 IU vitamin D sentezleyebilmektedir. ${ }^{18}$ ABD Ulusal Sağlık Akademisi tarafından 1-50 yaş arası bir kişide, güneş ışı̆̆ına maruz kalmadığı takdirde günlük $D$ vitamini ihtiyacını 200 IU/gün olarak bildirmiştir. Bu nedenle günlük yeteri kadar $\mathrm{D}$ vitamini almak için el ve yüz bölgesinin 15 dakika kadar güneş ışığına maruz kalması gerekmektedir. $^{7}$

D vitamininin dışarıdan diyetle alımı sınırlı olup, en fazla D vitamini yağıı balıklar (somon, sardalya, uskumru) ve yumurta sarısında bulunur. ${ }^{17}$ Diyetle alınan D vitamini formları ince bağırsakta absorpsiyona uğradıktan sonra, şilomikronlarla birleşerek lenfatik sistem aracılığıyla venöz dolaşıma katılmaktadır. Endojen olarak yapılan veya diyet yoluyla alınan $D_{2}$ vitamin ve $D_{3}$ vitamini vücutta yağ hücrelerinde depolanıp, ihtiyaç durumun da dolaşıma salıverilmektedir. ${ }^{16} \mathrm{D}$ vitamini ve metabolitlerinin atılımı tam olarak bilinmese de primer olarak feçes ve safra tuzları ile atıldığı, az miktarda da idrarla atıldığı düşünülmektedir. ${ }^{19}$

Diyetle alınan ve deride sentezlenen $D$ vitamini inaktiftir. Dolaşım sisteminde $D$ vitamini ve metabolitleri $D$ vitamini bağlayıcı proteinine bağlı olarak dolaşmaktadır. Bu proteinler dolaşımda 25(OH)D, 1 $\alpha, 25(\mathrm{OH})_{2} \mathrm{D}$ ve $24,25(\mathrm{OH})_{2} \mathrm{D}$ 'ye yüksek afinite gösterirler. $D$ vitamini bağlayıcı proteine bağlanarak karaciğere taşınan $D$ vitamini ve metabolitleri 25 hidroksilaz enzimi ile hidroksillenerek, 25-hidroksivitamin D'ye yani 25(OH)D formuna dönüşmektedir. D vitamininin aktif hale gelebilmesi için dolaşımdaki 25(OH)D formu sitokinlerin etkisi ile böbreklerde $1 \alpha$-hidroksilaz enzimi tarafından hidroksillenerek, $1,25(\mathrm{OH})_{2} \mathrm{D}^{\prime}$ ye yani kalsitriole dönüşmektedir. ${ }^{18} \mathrm{D}$ vitamininin metabolizması Şekil $\mathbf{1}^{\prime}$ de gösterilmiştir. ${ }^{20} \mathrm{D}$ vitamini metabolizması 25hidroksilasyon, 1 $\alpha$-hidroksilasyon ve 24-hidroksilasyon sitokrom P450 (CYP) oksidazlar tarafından gerçekleştirilmektedir. ${ }^{21} \mathrm{D}$ vitamininin sentezinde $1 \alpha$-hidroksilaz kritik öneme sahiptir. D vitaminin dolaşımdaki asıl formu 25(OH)D'dir. 25(OH)D konsantrasyonu 1,25(OH) $)_{2} \mathrm{D}^{\prime}$ nin yaklaşık olarak 1000 katı kadardır. ${ }^{16}$

Dolaşımdaki $1,25(\mathrm{OH})_{2} \mathrm{D}^{\prime}$ nin başlıca kaynağı böbrektir. 25-hidroksilasyonun aksine, 1 $\alpha$-hidroksilaz aktivitesine sahip olduğu kabul edilen sadece bir enzim vardır ve bu da CYP27B1'dir. Bu gen içindeki mutasyonların, yetersiz $1,25(\mathrm{OH})_{2} \mathrm{D}$ üretimi nedeniyle ortaya çıkan psödovitamin D eksikliğinin altında yatan neden olduğu gösterilmiştir. CYP27B1, D vitamini metabolizmasına katılan diğer mitokondriyal enzimlerle yüksek bir homoloji derecesine sahiptir: CYP27A1 ve CYP24A1'nin ana kaynağı böbrek olmasına rağmen, birtakım diğer dokular da enzimi ifade etmektedir ve extrarenal CYP27B1'in regulâsyonu renal CYP27B1'den farklıdır. Bu dokulara örnek olarak cilt, akciğerler, meme, bağırsak ve prostatta epitel hücreleri, paratiroid bezi, pankreatik adacıklar, tiroid, testisler, overler ve plasenta da dâhil olmak üzere endokrin bezleri, makrofajlar dâhil bağışıklık sisteminin hücreleri ve T ve B lenfositleri, dendritik hücreler, osteoblastlar, kondrositler ve bu hücrelerden türetilen çeşitli tümörler gösterilebilir. ${ }^{21}$

CYP24A1'in D vitamini metabolizması ile ilişkisi sadece 24-hidroksilasyon yapıyor olmasından kaynaklanmaktadır. Kemik oluşumu için hem $1,25(\mathrm{OH})_{2} \mathrm{D}$ hem de $24,25(\mathrm{OH})_{2} \mathrm{D}$ 'nin gerekli olduğu belirtilmektedir. Son zamanlarda ciddi hiperkalsemi, hiperkalsiüri ve nefrokalsinozis durumunda, azalmış paratiroit ve düşük $24,25(\mathrm{OH})_{2} \mathrm{D}$ 'ye sahip idiopatik infantil hiperkalsemili çocuklarda; CYP24A1'de inaktive mutasyonlar bulunmuştur. Bu nedenle, CYP24A1'in birincil fonksiyonunun, toksik seviyelerde $1,25(\mathrm{OH})_{2} \mathrm{D}$ ve 25(OH)D birikimini önlemek olduğu bildirilmiştir. ${ }^{21}$ Aslında sentezlendiği tüm hücrelerde CYP24A1, $1,25(\mathrm{OH})_{2} \mathrm{D}$ ile kuvvetli bir şekilde indüklenir ve genellikle bu hücrede $1,25(\mathrm{OH})_{2} \mathrm{D}$ yanıtının bir markeri olarak görülmektedir. ${ }^{21}$ 


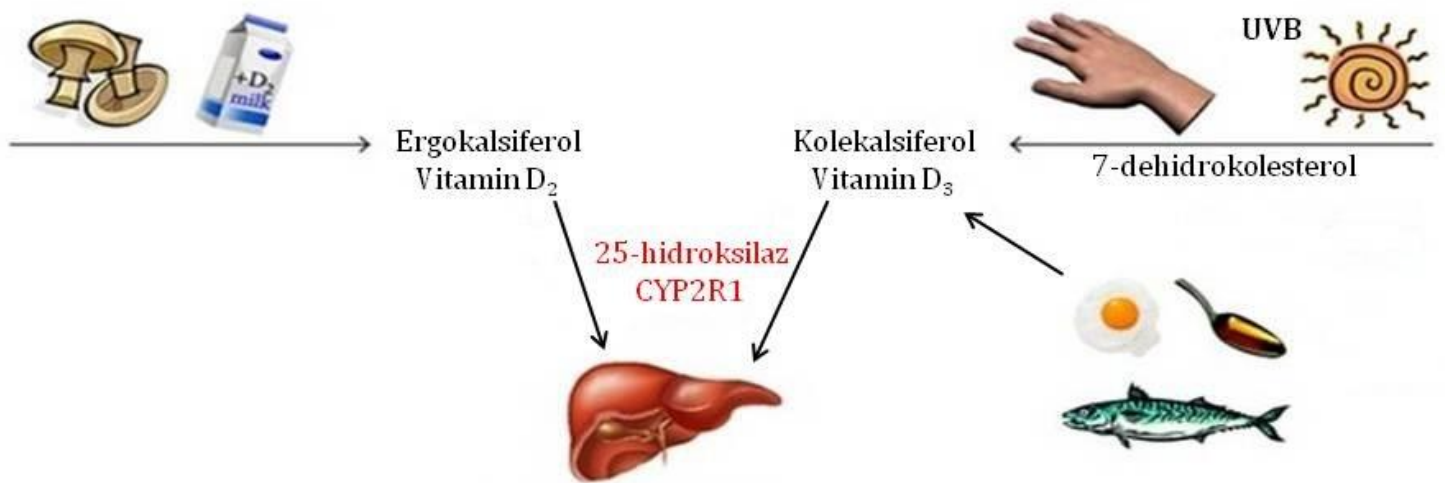

Kalsidiol $(25(\mathrm{OH}) \mathrm{D})$

Kandaki D vitamininin primer formu

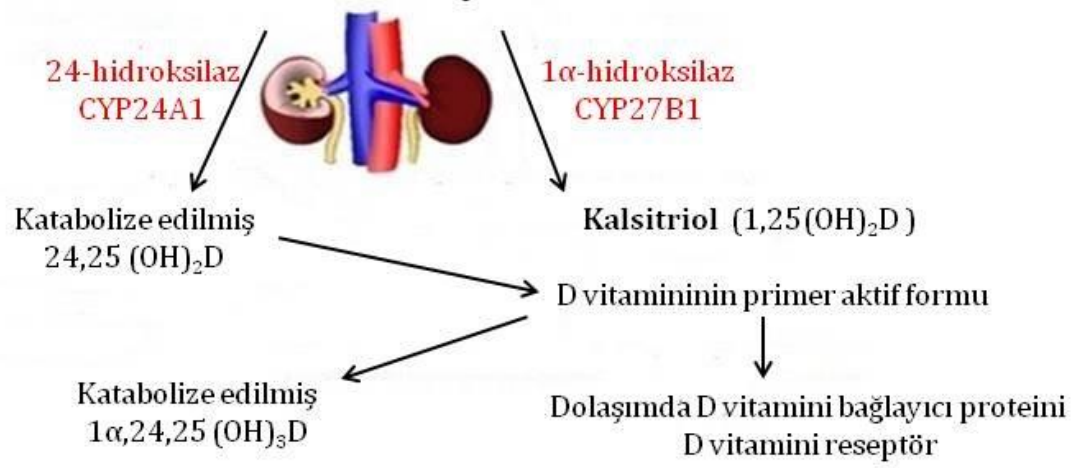

Şekil 1. D vitamini sentezi ve metabolizması. ${ }^{20}$

CYP24A1'in temel rolünün dokulardaki $1,25(\mathrm{OH})_{2}$ D seviyelerini kontrol etmek olduğu ve bazı malignitelerin CYP24A1 ekspresyonunu arttırdığı göz önüne alındığında, $1,25(\mathrm{OH})_{2} \mathrm{D}$ 'nin bu hücrelerde antiproliferatif/prodiferansiye edici etkilerini arttırma umuduyla, tümörlerde endojen $1,25(\mathrm{OH})_{2} \mathrm{D}$ seviyesini arttırmak için CYP24A1 inhibitörlerini geliştirmeye yönelik çalışmalar yapılmıştır. Daha yakın zamanlarda, fenil sülfoksimin D-halkası (24(S)-NH) yan zincirine sahip bir D vitamin analoğu olan CTA091; VDR'ne bağlanma özelliği olmadan geliştirildi, fakat bu ajanın CYP24A1 inhibisyonu için son derece seçici olduğu bildirilmiştir. CTA018 gibi diğer D vitamini analogları, hem VDR agonist aktiviteye, hem de CYP24A1 ekspresyonu için selektif antagonist aktiviteye sahiptir. ${ }^{21,22}$

D vitamini metabolizması özetlenirse, D vitaminin sentezinde 1 alfahidroksilaz kilit noktadır. 1 alfahidroksilaz enzim aktivitesinin düzenlenmesinde paratiroit hormonu, kalsiyum, fosfor ve FGF23 rol oynar. Kandaki kalsiyum ve fosfor düzeylerinin düşmesi ile artan paratiroit hormonu, $D$ vitamini üretimini artırmaktadır (1 alfahidroksilaz aktivitesi artışı). Fakat FGF23, 1,25(OH) 2 D sentezini baskılar ve 24 hidroksilaz enzim aktivasyonunu artırarak, $1,25(\mathrm{OH})_{2} \mathrm{D}^{\prime}$ nin inaktif forma dönüşmesine neden olmaktadır. ${ }^{23}$

\section{Vitamini Reseptörü}

D vitamini reseptör (VDR) ekspresyonu yağ, beyin, kolon, karaciğer, akciğer, kas, over, pankreas, prostat, deri, mide ve tiroit de dâhil olmak üzere çeşitli doku tiplerinde gösterilmiştir. ${ }^{24} \mathrm{D}$ vitamini reseptörleri; vasküler düz kas, endotel ve kardiyomiyositleri de içeren geniş çeşitlilikte doku dağılımlılarına sahiptir. Ayrıca, 25(OH)D’nin, 1,25(OH $)_{2} \mathrm{D}^{\prime}$ ye dönüşmesi hem vasküler düz kas hem de endotelyal hücrelerinde olabilmektedir. ${ }^{25} 1,25(\mathrm{OH})_{2} \mathrm{D}_{3}$ hücreye girerek, nükleer $\mathrm{D}$ vitamini reseptörüne bağlanmaktadır. $\mathrm{D}$ vitamini reseptörü ve $1,25(\mathrm{OH})_{2} \mathrm{D}_{3}$ kompleksi, retinoid asit-x reseptörü ile heterodimer oluşturur ve ilgili gen üzerindeki $D$ vitaminine duyarlı elemente bağlanarak protein sentezini (kalsiyum bağlayıcı protein veya osteokalsin) indükleyen nükleer transkripsiyon faktörü olarak görev yapar. Nükleer $D$ vitamini reseptörü deri, kas, hematolenfopetik, sinir, üreme ve endokrin sistem dokularında mevcut iken, osteoklast hücrelerinde bulunmamaktadır. Bu nedenle $1,25(\mathrm{OH})_{2} \mathrm{D}_{3}$ bu hücreleri indirekt non-genomik bir mekanizma 
ile etkilemektedir. ${ }^{18} 1,25(\mathrm{OH})_{2} \mathrm{D}_{3}$ reseptörü birçok doku da bulunduğu gibi benign hiperplastik ve malign epitelyal ve fibroblastik dokularda da mevcuttur. $1,25(\mathrm{OH})_{2} \mathrm{D}_{3}$ direkt veya indirekt olarak insülin üretimi, renin üretimi, sitokin salıverilmesi, kardiyomiyosit ve vasküler düz kas hücrelerinin proliferasyonu ve büyümelerinden sorumlu genleri de içeren yaklaşık iki yüz geni regüle etmektedir. ${ }^{25}$

\section{Vitamini Düzeyi}

İnsanlarda D vitamini düzeyini değerlendirmek için kanda 25(OH)D düzeyine bakılmaktadır. 25(OH)D düzeyi vücutta hem diyetle alınan hem de endojen olarak yapılan D vitamininin göstergesi olarak kabul edilmektedir. 25(OH)D'nin yarılanma ömrü 2-3 hafta iken, $1,25(\mathrm{OH})_{2} \mathrm{D}^{\prime}$ nin yarılanma ömrü ise 4-6 saattir. Aynı zamanda $1,25(\mathrm{OH})_{2} \mathrm{D}^{\prime}$ nin dolaşımdaki düzeyi 25(OH)D düzeyinden 1000 kat daha düşüktür. Bu nedenle dolaşımdaki D vitaminin en iyi göstergesi $25(\mathrm{OH}) \mathrm{D}$ düzeyi olarak kabul edilmektedir. ${ }^{13}$

Yapılan araştırmalarda D vitamininin kandaki güncel 25(OH)D düzeyleri değerlendirildiğinde 25(OH)D düzeyi; $5 \mathrm{ng} / \mathrm{mL}$ 'den düşük olması ağır $D$ vitamini eksikliği, $5-10 \mathrm{ng} / \mathrm{mL}$ arasında olması $D$ vitamini eksikliği, 10-20 $\mathrm{ng} / \mathrm{mL}$ arasında olması $D$ vitamini yetersizliği, $20-30 \mathrm{ng} / \mathrm{mL}$ arasında olması $D$ vitamininin sınırda, 30-60 $\mathrm{ng} / \mathrm{mL}$ arasında olması $D$ vitamini için tercih edilen aralığı, $150 \mathrm{ng} / \mathrm{mL}$ 'den yüksek olması $D$ vitamini intoksikasyonu olarak tanımlanmıştır. Yapılan araştırmalara göre, D vitamininin kanda güncel 25(OH)D düzeyleri Tablo 2'de verilmiştir. 5,16,17,26

Tablo 2. D vitamininin, kandaki 25(OH)D düzeylerine göre değerlendirilmesi. 5,16,17,26

\begin{tabular}{|l|c|c|}
\hline \multirow{2}{*}{ D Vitamini Tanımları } & $\mathbf{2}$ & 25 (OH)D Düzeyi \\
\cline { 2 - 3 } & $\mathbf{n g} / \mathbf{m L}$ & $<12$ \\
\hline Ağır D Vitamini Eksikliği & $<5$ & $12-25$ \\
\hline D Vitamini Eksikliği & $5-10$ & $25-50$ \\
\hline D Vitamini Yetersizliği & $10-20$ & $50-75$ \\
\hline D Vitamini Sınırı & $20-30$ & $75-150$ \\
\hline D Vitamini Yeterliliği & $30-60$ & $>375$ \\
\hline D Vitamini Toksisitesi & $>150$ & \\
\hline
\end{tabular}

Günlük alınması önerilen D vitamini miktarı 800-1000 IU olarak belirtilmiştir, bu miktar D vitamini seviyesini kanda $30-60 \mathrm{ng} / \mathrm{mL}$ arasında tutmayı amaçlamaktadır. Aynı zamanda araştırmacılar günde $100 \mathrm{IU}$ (2.5 mcg) D vitamininin, 2-3 ay sonra serum $25(\mathrm{OH}) \mathrm{D}$ düzeyini sadece $1 \mathrm{ng} / \mathrm{mL}$ veya $2,5 \mathrm{nmol} / \mathrm{L}$ arttırabileceğini bildirmişlerdir. Yapılan çalışmalarda $100 \mathrm{IU}$ ile $2000 \mathrm{IU}$ arasındaki miktarlarda alınan D vitamini miktarının 23 ay sonra kanda D vitamini düzeyini aynı oranlarda artırmıştır. ${ }^{27}$ Creighton Üniversitesi'nde Dr. Robert Heaney ve arkadaşlarının yaptığı çalışmalarda, tüm yetişkinlerin yaklaşık $75 \mathrm{nmol} / \mathrm{L}$ D vitamini (kalsidiol) seviyesine sahip olması gerektiğini bildirmişlerdir. ${ }^{28}$

D vitamini intoksikasyonunun, sağlıklı bir bireye üç aydan fazla günde 10.000 IU verilmesi halinde ortaya çıkabileceği bildirilmiştir. Yapılan araştırmalar, D vitamininin yüksek doz alımının kanser riskini azaltabileceği gibi, böbrek ve karaciğer üzerine zarar verebileceğini de göstermiştir. ${ }^{18}$ Kişilerde $D$ vitamini intoksikasyonunun belirtileri; kusma, iştahsızlık, baş ağrısı, yüksek tansiyon, aritmi, hiperkalsemi, fiperfosfatemi, hiperkalsiüri, damar kalfisikasyonu, nefrokalsinoz ve böbrek yetmezliği gelişimi olabilmektedir. ${ }^{23}$

\section{Vitaminin Genomik ve Non-Genomik Etkileri}

D vitamini hücrelerde VDR aracılı gen trankripsiyonu ve VDR bağımsız non-genomik etki mekanizması olmak üzere iki farklı yolla etki gösterir. $1,25(\mathrm{OH})_{2} \mathrm{D}$ 'nin tüm genomik etkilerine VDR aracılık eder. VDR, bir transkripsiyon faktörüdür ve steroid hormon nükleer reseptör ailesinin üyesidir. D vitamini kompleksi retinoid (genellikle RXR) reseptörü ile heterodimer oluşturarak ilgili gen üzerindeki " $D$ vitaminine duyarlı elementine" bağlanır. Bu kompleksler hem gen hem de hücreye spesifik olabilir; bu durum $1,25(\mathrm{OH})_{2} \mathrm{D}$ cevabının hücre tipinden hücre tipine seçiciliğini sağlamaktadır. Bu kompleksler, çoğunlukla bir LXXLL motifi 
vasıtasıyla VDR'ye direkt olarak bağlanan bir alt birimi, histon asetil transferazları, deasetilazları, metil transferazları ve demetilazları, ATP'yi nükleozomal-yeniden şekillendirici aktivite olarak içeren enzim aktivitesi ve RNA'ya bağlanan polimeraz II'yi içerir. ${ }^{21}$

D vitaminin non-genomik etkileri; hormon sekresyonunun düzenlenmesi, immün fonksiyonların düzenlenmesi, hücre proliferasyon ve farklılaşmasının düzenlenmesi olarak tanımlanabilecek yanıtlarda tespit edilmiştir. ${ }^{29} 1,25(\mathrm{OH})_{2} \mathrm{D}$ non-genomik etkilerini, genomik etkilerden çok daha hızlı gösterir ve kısa süren etkilerdir. Genomik etkiler genellikle protein sentezi gerektirirken, non-genomik etkiler hazırda bulunan ikincil mesajcılar aracılığıyla gerçekleşmektedir. Bu etkilerden bir tanesi, D vitamininin bağırsaklardan kalsiyum taşınmasının hızla uyarılmasını sağlamaktadır. $1,25(\mathrm{OH})_{2} \mathrm{D}^{\prime}$ nin reseptörünü tanıması, non-genomik VDR agonistleri ve membrana duyarlı steroid bağlayıcı protein olan ERp57/GRp58/ERp60 olarak da bağlanmayı sağlamak için farklı bir konfigürasyonda olsa da VDR'nin kendisine odaklanmıştır. Bu reseptörler kinazları, fosfatazları ve iyon kanallarını harekete geçirmek için büyük miktarlarda caveolae/lipid membranında bulunmaktadır. ${ }^{18}$

\section{Vitamini Eksikliği ve Tedavisi}

D vitamini, son 15 yıldır bilimsel ve tıbbi toplulukların, düzenleyici kurumların, gıda endüstrisinin ilgisini çeken bir konu haline gelmiştir. Bu konu, bilimsel literatürde yapılan araştırmaların yoğunlaşmasına, bazı ülkelerde hastalarda $D$ vitamini düzeyi için talep edilen testlerde önemli ölçüde artışına, kanıtlanmış bazı beslenme tavsiyeleri ve $D$ vitamini takviyeleri satışı ve $D$ vitamini kullanım miktarının artmasına yol açmıştır. Avrupa ülkelerinde D vitamini eksikliği için doğrudan ve dolaylı maliyetlerin yüzlerce milyar Avro'ya ulaştığı tahmin edilmektedir. ${ }^{30}$ Dünyada $D$ vitamini eksikliği veya yetersizliğinin 1 milyar kişide olduğu tahmin edilmektedir. ${ }^{23}$ Ülkemizde ise yapılan bir çalışmada D vitamini eksikliği yaklaşık \% 80 olarak bildirilmiştir. ${ }^{31}$ Yine yapılan başka bir çalışmada, Ülkemizde her 10 kişiden dokuzunda D vitamini eksikliğinin görüldüğü ve yetişkin kadınlarda daha yaygın olduğu bildirilmiştir. ${ }^{32}$

D vitamini düzeyi bazı etmenlere bağlı değişiklik gösterse de, $25(0 \mathrm{H}) \mathrm{D}^{\prime}$ nin $20 \mathrm{ng} / \mathrm{mL}$ 'den düşük olması $\mathrm{D}$ vitamini eksikliği olarak tanımlanmıştır. D vitamini eksikliği kemik mineralizasyonun bozulmasına yol açarak, çocuklarda raşitizm, yetişkinlerde ise osteomalazi ve osteoporoza neden olabilmektedir. ${ }^{7,21,30} \mathrm{D}$ vitamini eksikliğinin belirtileri halsizlik, yorgunluk, depresyon eğilimi, vücutta kramp hissi şeklinde olabilmektedir. ${ }^{33}$ D vitamini eksikliğinin risk faktörleri ise; kutuplara yakın bölgelerde yaşama, güneşe maruziyetin azlığı, koyu cilt, ileri yaş, obezite, güneş koruyucu kremler, D vitamini metabolizmasının artması (lenfoma, hiperparatiroidi), malabsorbsiyon, kronik böbrek yetmezliği ve antikonvülzan ilaç kullanımı olarak sayıllabilir. ${ }^{34}$

Yaygın bir sağlık sorunu olarak kabul edilen D vitamini eksikliğine karşı önlem almak gerekmektedir. ${ }^{35}$ Yapılan son çalışmalarda, D vitamini eksikliğinin önlenmesinde hem halk sağlığı hem de klinik çalışmaların stratejilerinin önemi vurgulanmıştır. ${ }^{30} \mathrm{D}$ vitamini eksikliğinin önlenmesine yönelik, risk grubundaki kişilerde mutlaka serum 25(OH)D düzeyi bakılması gerekmektedir. ${ }^{33} \mathrm{D}$ vitamini eksikliğinin önlenmesine yönelik tedavi önerileri şunlar olabilir;

- Saat 10:00 ile 15:00 arasında yüz ve kolların güneş ışığına direkt maruz bırakılması, (açık tenli kişilerin yaklaşık günde 15 dakika, koyu ciltlerde ise yaklaşık bu sürenin 3-4 katı)

- Kemik ve kas sağlığı için gerekli minimum günlük D vitamini ihtiyacı 0-1 yaş arası bebeklerde 400 IU/gün, 1-70 yaş arasında $600 \mathrm{IU} / g u ̈ n, 70$ yaş üzerindeki kişilerde ise $800 \mathrm{IU} / g u ̈ n ' d i r$.

- D vitamini eksikliği açısından riskli bireyler (antikonvülzan, glukokortikoidler gibi ilacı kullananlar, obez, vb.) kendi yaş grubu için günlük önerilen D vitamini miktarının en az 2-3 kat daha fazlasını almalıdır.

- 25(OH)D düzeyi $20 \mathrm{ng} / \mathrm{mL}$ altında olan yetişkinlere yükleme olarak, iki ay boyunca haftada bir kez 50000 IU D vitamini verildikten sonra 1500-2000 IU/gün idame olarak devam etmesi gerekmektedir. ${ }^{33}$ 
D vitamini eksikliği tanısı konmuş ve tedavi başlanmış bireylerde serum 25(OH)D düzeyine 3-6 hafta sonra mutlaka bakılması gerekmektedir. Eğer serum 25(OH)D düzeyi hedef düzeye ulaşmamışsa tekrardan ek doz verilmesi gerekebilir. ${ }^{33}$

\section{Vitamini ve Kanser}

D vitaminin antikanserojen etkisine, ilk olarak Apperly'nin Kuzey Amerika'da kanser mortalitesi ve solar radyasyon arasındaki ilişkiyi gözlemlemesiyle dikkat çekilmiştir. ${ }^{36}$ Yapılan araştırmalar kuzey kutbunda yaşayan popülasyonda kanser görülme oranını, güney kutbunda yaşayan popülasyondan daha yüksek olduğunu göstermiştir. ${ }^{37} \mathrm{D}$ vitaminin olası antikansorojen etkisinin ortaya çıkabilmesi için serum $25(\mathrm{OH}) \mathrm{D}$ değeri $30 \mathrm{ng} / \mathrm{mL}^{\prime}$ dan yüksek olması gerekmektedir. 1,25(OH) ${ }_{2} \mathrm{D}^{\prime}$ nin kanser hücrelerinde proliferasyon, metastaz, invazyon ve anjiogenez üzerine azaltıcı, apoptozis ve diferansiasyon üzerine de artıcı etkileri vardır. ${ }^{38} \mathrm{D}$ vitamininin kanser üzerindeki etki mekanizması; hücre büyümesini inhibe eden sinyalleri ve hücre farklılaşmasını arttııı, hücre büyümesini tetikleyen sinyalleri, hücre proliferasyonunu, metastazı ve anjiogenezi inhibe etmesi şeklinde açıklanabilir. ${ }^{7}$ Yine başka bir çalışmada $1,25(\mathrm{OH})_{2} \mathrm{D}_{3}$ ve analogları, $\mathrm{D}$ vitamini reseptörünün aracılık ettiği insan kanser hücrelerinin çoğalmasını inhibe ettiğini göstermiştir. ${ }^{8} \mathrm{D}$ vitamini reseptörünün bugün pek çok dokuda bulunduğu gösterilmiştir. ${ }^{9-11}$ Yapılan çalışmalar, D vitamininin ve reseptörünün jinekolojik kanserlerin gelişiminde önemli bir rol oynadığını düşündürmektedir. ${ }^{12}$

Endometriyal kanserlerin erken dönemde teşhis edilen hastalarda, beş yıllık sağkalım oranı \%74 ile \%91 arasında değişmektedir. Endometriyal kanser gelişimi için sorumlu faktörler yaşlılık, nulliparite, diyabet, östrojen hormonu replasman tedavisi ve obezite olarak sıralanabilir. Son yıllarda yapılan çalışmalar göğüs, kolorektal ve akciğer kanseri gibi bazı kanser türlerinin patogenezinde D vitamininin rolü ile ilişkisini ortaya koymaktadır. Literatürde, D vitamini seviyelerinin ve D vitamini ile ilişkili yolakların jinekolojik kanser riskini etkilediğini gösteren çalışmalar mevcuttur. Aynı zamanda endometriyal, ovarian, servikal, vulvar ve vajinal kanserlerde $D$ vitamini ve $D$ vitamini reseptörünün etkisini sistematik olarak analiz eden çok sayıda çalışma bulunmaktadır. Çok sayıda ekolojik çalışma, UVB maruziyeti ile jinekolojik kanser riski arasındaki ters ilişki hakkında kanıt sunmaktadır. ${ }^{12}$

Jinekolojik kanserlerde $D$ vitamini ve $D$ vitamini reseptörünün rolü: Jinekolojik kanser dokusu kadar farklı dokuların da kalsitriol sentezleyebildikleri gösterilmiştir. Buna ek olarak D vitamini ve reseptörünün, jinekolojik kanserlerde koruyucu bir role sahip olduğu gösterilmiştir. Yine yumurtalık, servikal ve vulvar kanserlerde düşük $D$ vitamini seviyeleri tespit edilmiştir. Birçok in vivo ve in vitro çalışma, inflamasyon, insülin benzeri büyüme faktörü sinyali ve östrojen ile ilişkili yolaklarda VDR'nin bir aracı olarak önemini ortaya koymuştur. Dahası, VDR, önemli miktarda tümör dokusunda eksprese edilir ve bu da reseptörün kanser etyolojisini etkilediğini göstereblir. VDR polimorfizmlerinin D vitamini-VDR kompleksinin aktivitesini değiştirdiği gösterilmiştir. Kansere yanıt olarak, D vitamini reseptörünün ekspresyonu endometriyal, over, servikal ve vulvar kanserlerinde upregüle olmaktadır. VDR/RXR'nin endometriyal, servikal, vulvar veya vajinal kanser hastalarının hayatta kalması üzerindeki rolü hakkında sınırlı bilgi olmasına rağmen, bazı çalışmalar her iki reseptörün sağ kalımı etkilediğini göstermiştir. Bu nedenle, daha ileri çalışmaların jinekolojik kanserlerde $D$ vitamini ve onun hetero-dimer reseptörü RXR üzerinde yoğunlaşması gerektiğini önermektedirler. Jinekolojik kanserlerde $D$ vitamini ve $D$ vitamini reseptörünün rolü Şekil $\boldsymbol{2}^{\prime}$ de gösterilmiştir. ${ }^{12}$

Çok sayıda çalışma D vitamini ve D vitaminin kaynağı güneş ışınlarının (UVB) kansere karşı koruyucu olduğunu göstermiştir. Güneş ışınlarına maruziyetin melanom gelişim riskini arttırdığını gösteren çalışma bulunmakla birlikte melanomlu hastalarda survival oranlarında artış sağlayabileceğini gösteren çalışmalar da mevcuttur. ${ }^{6,7}$ Yine güneş ışınlarına maruziyetin cilt kanserine yol açtığını da gösteren çalışmalar vardır. Bu nedenle D vitamini için önemli bir kaynak olan UVB ışınına gün içerisinde, doğru saatlerde yeteri kadar, kontrollü ve uyarılara uygun şekilde maruz kalmak gerektiği önerilmektedir. ${ }^{7}$

D vitamini eksikliği veya yetersizliği de hem ülkemizde hem dünyada yaygın olarak görülmektedir. ${ }^{13,32} \mathrm{D}$ vitamini eksikliği ile kanser arasında ilişkiyi gösteren çok sayıda çalışma vardır. Çalışmalar güney kutbuna kıyasla kuzey kutbunda yaşayan kişilerde pankreas, prostat, kolon, hodgkin lenfoma ve akciğer kanserlerine yakalanma oranı ve bu kanserlere bağlı ölüm oranlarının artırdığını göstermiştir. ${ }^{23}$ Epidemiyolojik çalışmalar 
düşük $D$ vitamini düzeyinin prostat, meme ve kolorektal kanser riskinin artışı ile ilişkili olduğunu göstermiştir. ${ }^{39-42}$ Yine başka bir çalışma da 25(OH)D düzeylerinin $20 \mathrm{ng} / \mathrm{mL}$ 'nin altına düştüğünde kolon, pankreas, prostat, meme kanseri insidansının \%30-50 arttığı ve bu kanserlere bağlı mortalitenin de arttığını göstermiştir. ${ }^{43}$

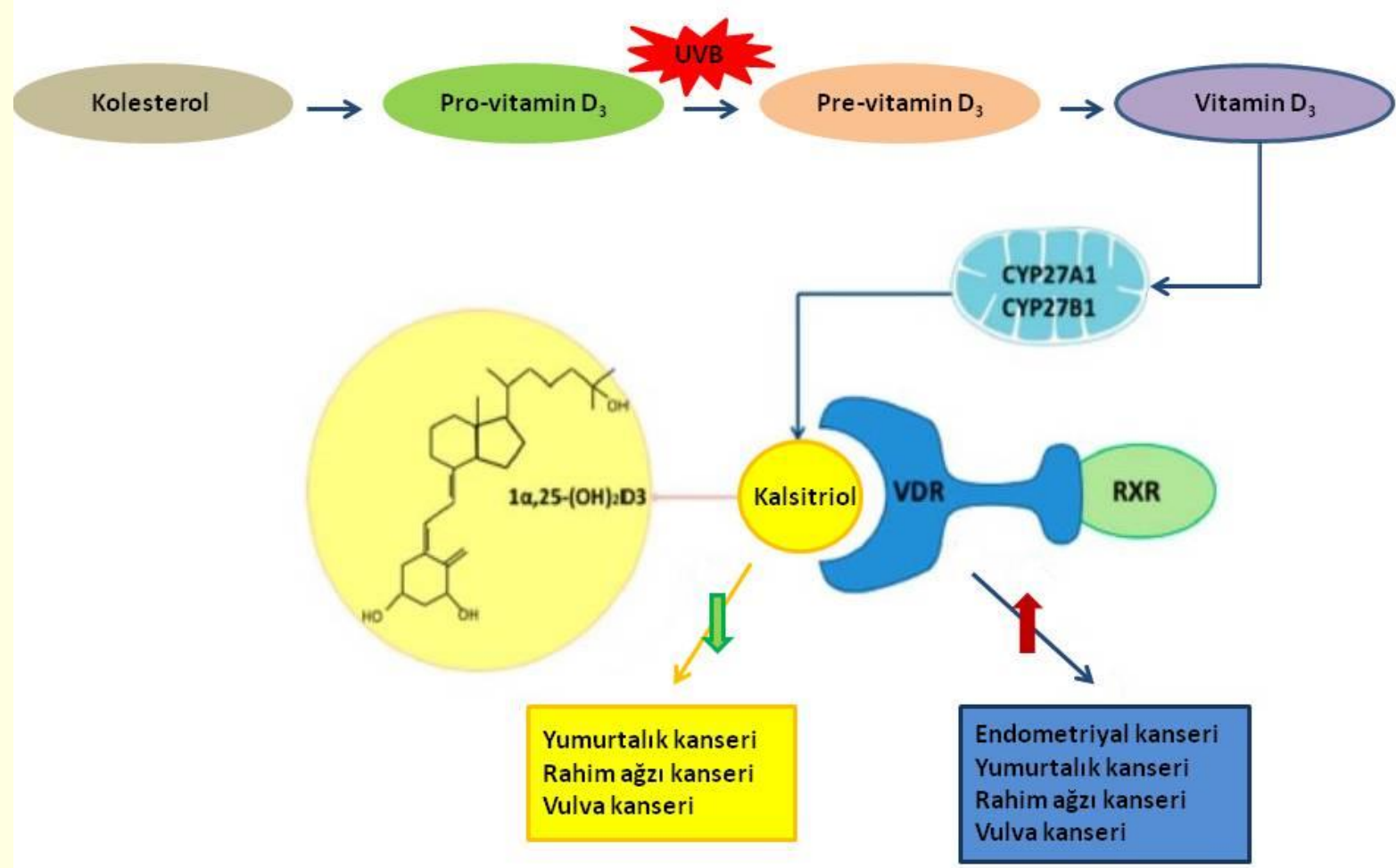

Şekil 2. Jinekolojik kanserlerde $D$ vitamini ve $D$ vitamini reseptörünün rolü. ${ }^{12}$

D vitamini ile kolorektal kanserler arasındaki ilişki konusunda; birçok çalışma günlük olarak alınan $D$ vitamininin kolorektal kanser gelişim riskini anlamlı olarak azalttığını göstermiştir. 3 farklı kohort çalışmada alınan D vitamini dozu yükseldikçe kolorektal kanser gelişme riskinin azaldığı gösterilmiştir. 2011 yılında yayınlanan bir meta-analizde ise, yüksek serum 25(OH)D düzeyinin kolorektal kansere karşı koruyucu özellik sağladığını bildirmiştir. Buna karşın, postmenapozal kadınlarda $D$ vitamini replasmanının invaziv kolorektal kanser gelişim riskinde azalmaya yol açmadığı da bildirilmiştir. ${ }^{7}$ Ancak düşük $D$ vitamini düzeyi uzun süredir kolorektal karsinogenezisle ilişkilendirilmektedir. D vitamini alımı ile erkeklerde kolorektal kanser arasında doğrudan bir ilişki olduğu ve riskin $D$ vitamini alımı arttıkça azaldığı gösterilmiştir. ${ }^{44}$ Yapılmış büyük gözlemsel bir çalışmanın sonuçları, batı Avrupa popülasyonlarında pre-diagnostik 25(OH)D konsantrasyon seviyeleri ve kolorektal kanser riski seviyeleri arasında güçlü ters bir ilişki olduğunu ortaya koymaktadır. ${ }^{45}$

D vitamini ile meme kanseri arasındaki ilişki tartışmalıdır. 25(OH)D düzeyi ile ilişki gösteren ve gösteremeyen; D vitamini alımına olumlu yanıt alan ve alamayan çalışmalar mevcuttur. Yakın zamanda yapılan bir çalışmada serum $25(\mathrm{OH}) \mathrm{D}$ düzeyleri $20 \mathrm{ng} / \mathrm{mL}$ 'den düşük ve kalsiyum düzeyleri $10.5 \mathrm{mg} / \mathrm{dl}$ 'den düşük olanlarda meme kanseri olma ihtimalinin yüksek olduğu gösterilmiştir. ${ }^{46}$ iki farklı kohort çalışmasında ise premenapozal dönemdeki kadınlarda yüksek doz D vitamini alımı ile meme kanseri gelişim riskinde istatistiksel olarak anlamlı azalma izlendiği gösterilmiş, ancak benzer koruyucu etki postmenapozal dönemdeki kadınlarda izlenmemiştir. Yine yapılan çalışmalarda postmenapozal kadınlarda D vitamini replasmanının invaziv kolorektal kanseri gelişim riskinde azalmaya yol açmadığı da bildirilmiştir. ${ }^{7}$ Başka bir meta-analiz çalışmasında, premenapozal dönemde değil ama postmenapozal dönemde D vitamini $25(\mathrm{OH}) \mathrm{D}$ düzeyi ile meme kanseri arasında ters ilişki saptanmıştır. Bu çalışmaya göre özellikle $27-35 \mathrm{ng} / \mathrm{ml}$ arasındaki 
seviyelerde, her $5 \mathrm{ng} / \mathrm{ml}$ artış, kanser riskini \%12 kadar azaltmış; $35 \mathrm{ng} / \mathrm{mL}$ 'nin üstündeki dozlarda bu ilişkinin zayıfladığı bidirilmiştir. ${ }^{47}$ Buna karşılık bir çalışmada ise postmenapozal dönemde 7 yıl takip edilen 36282 kadının, günde 1000 mg kalsiyum ve 400 iÜ D vitamini desteği alınmasının, plasebo alanlara göre invaziv meme kanseri riskinde bir fark yaratmadığı gösterilmiştir. ${ }^{48}$

D vitamini durumu ile pankreas kanseri riski arasındaki ilişki tam olarak net değildir. Yakın zamanda yapılan çalışmada 11 tane D vitamini ilişkili gen ile pankreatik adenokarsinoma ile ilişkileri incelenmiş, fakat bulgular D vitamini ilişkili genler ile pankreatik kanser riski arasındaki ilişkiyi desteklememiştir. ${ }^{49}$ Pankreas kanseri dokusunda $D$ vitamini reseptörü gösterilmiştir, ancak kalsitriol analogları doğrudan pankreas dokusunu etkilememektedir. Pankreas kanserinde kalsitriol analoglarının kullanımı büyük ölçüde yetersizdir ve bu nedenle daha ileri klinik araştırmaları ihtiyaç bulunmaktadır. ${ }^{50}$

D vitamini ve akciğer kanseri arasındaki ilişki; son yıllarda, göğüs, kolorektal ve akciğer kanseri gibi bazı kanser türlerinin patogenezinde $D$ vitamininin rolü üzerinde yoğun çalışmalar yapılmaktadır. ${ }^{12}$ ilk çalışmalar, dolaşımdaki 25(OH)D düzeyinin akciğer kanseri hastalarının prognozu üzerine muhtemel bir etkisini önermesine karşın çelişkili bulgular da bildirilmiştir. Yakın zamanda yapılan bir çalışmada dolaşımdaki 25(OH)D düzeyi ile genel sağkalım arasında bir korelasyon olduğunu göstermektedir. D vitamini ile akciğer kanseri arasındaki ilişkiyi tam olarak ortaya koyabilmek için daha fazla çalışmanın yapılmasına ihtiyaç duyulmaktadır. ${ }^{51}$

D vitamini ve prostat kanseri arasındaki ilişkisi tam olarak aydınlatılmış değildir. Epidemiyolojik çalışmalar düşük D vitamini düzeyinin prostat, meme ve kolorektal kanser riskinin artışı ile ilişkili olduğunu göstermiştir. ${ }^{39-42}$ Fakat başka bir kohort çalışmada ise $D$ vitamini alımının prostat kanseri gelişimi üzerinde koruyucu etki göstermediği bildirilmiştir. ${ }^{7}$ Son zamanlarda yapılan çalışmalar D vitamini takviyesinin prostat, göğüs ve kolorektal kanserler ve melanom üzerine etkisine odaklanmış ve bu çalışmalarda, beyaz ve siyah hastalar arasında farklılıkların olduğunu bildirmiştir. Bu nedenle D vitamini ile prostat kanseri arasındaki ilişkiyi ortaya konması için daha fazla çalışmanın yapılması gerekmektedir. ${ }^{52}$

Sonuç olarak D vitamini bazı kanserler için tartışmalı olsa da birçok kanser türü için eksikliği risk normal seviyelerde olması ise protektif etki gösterdiğini önermekteyiz. Bu nedenle kanserden korunmak amacıyla D vitamininin normal kan düzeylerinin sağlanması kritik öneme sahiptir. İnsanların kolaylıkla erişebileceği güneş ışınlarından bilinçli şekilde faydalanmak ve gerekli durumlarda besinlerle ve ilaç olarak alınarak kandaki gerekli $D$ vitamini düzeyi sağlanabilir. Bu alandaki çalışmaların teşvik edilmesi çeşitli kanserlerin patogenezinin aydınlatılmasına, hastalığın oluşması ve progresyonunun önlenmesine katkı sağlayabilir.

\section{KAYNAKLAR}

1. Thorne J, Campbell MJ. The vitamin D receptor in cancer. Proc Nutr Soc. 2008 May;67(2):115-27.

2. Giovannucci E. The epidemiology of vitamin D and cancer incidence and mortality: a review (United States). Cancer Causes Control. 2005 Mar;16(2):83-95.

3. Kuittinen T, et al. Paclitaxel, Carboplatin and 1,25-D3 Inhibit Proliferation of Endometrial Cancer Cells In Vitro. Anticancer Res. 2017 Dec;37(12):6575-6581.

4. Buggio L, Roncella E, Somigliana E, Vercellini P.Vitamin D and benign gynaecological diseases: a critical analysis of the current evidence. Gynecol Endocrinol. 2016;32(4):259-263

5. Holick MF. Vitamin D deficiency. N Engl J Med. 2007 Jul 19;357(3):266-81.

6. Whayne TF. Vitamin D: Popular Cardiovascular Supplement But Benefit Must Be Evaluated. Int J Angiol. 2011 Jun; 20(2): $63-72$.

7. Feldman D, et al. The role of vitamin D in reducing cancer risk and progression. Nat Rev Cancer. 2014;14(5):342-57.

8. Urbschat A, et al. Vitamin D hydroxylases CYP2R1, CYP27B1 and CYP24A1 in renal cell carcinoma. Eur J Clin Invest. 2013 Dec;43(12):1282-1290.

9. Nemere I, Carson F. Membrane receptors for steroid hormones: a case for spesific cell surface binding sites for vitamin D metabolites and estrogens. Biochem Biophys Res Com. 1998; 248:442-9.

10. Norman AW. Receptors for 1,25(OH)2D3: past, present and future. J Bone Miner Res. 1998;13:1360-1369.

11. De Luca HF, Cantorna MT. Vitamin D: its role and uses in immunology. FASEB J. 2001 Dec;15(14):2579-2585. 
12. Deuster E, et al. Vitamin D and VDR in Gynecological Cancers-A Systematic Review. Int J Mol Sci. 2017 Nov 4;18(11).

13. Fidan F, Alkan BM, Tosun A. Çağın Pandemisi: D Vitamini Eksikliği ve Yetersizliği. Türk Osteoporoz Dergisi. 2014;20: 71-74.

14. Liu JJ, et al. Prospective analysis of vitamin D and endometrial cancer risk. Ann Oncol. 2013 Mar;24(3):687-92

15. Garland CF, et al. Vitamin D for cancer prevention: global perspective. Ann Epidemiol. 2009 Jul;19(7):468-483.

16. Holick MF. Vitamin D Deficiency Medical Progress. N Engl J Med. 2007;357:266-81

17. Holick MF. High Prevalence of Vitamin D Inadequacy and Implications for Health. Mayo ClinProc. 2006;81:353-373.

18. Gökalp Özkorkmaz E. Vitamin D ve Biyolojik Önemi. Biyoloji Bilimleri Araştırma Dergisi. 2009; 2(2): 11-15.

19. Zempleni J. Handbook of vitamins. 4th ed. CRC Press. New York. 608 p.

20. Vitamin D metabolic pathways [Internet]. Erişim: https://www.researchgate.net/figure/Vitamin-D-metabolism-pathwayProteins-with-genetic-polymorphisms-associated-with-vitamin_264631440. Erişim tarihi: 20.12.2017.

21. Daniel D. Bikle. Vitamin D Metabolism, Mechanism of Action, and Clinical Applications. Chem Biol. 2014;21(3): 319-329.

22. Posner GH, et al. Vitamin D analogues targeting CYP24 in chronic kidney disease. J Steroid Biochem Mol Biol. 2010 Jul;121(1-2):13-19.

23. Öngen B, Kabaroğlu C, Parıldar Z. D Vitamini'nin Biyokimyasal ve Laboratuvar Değerlendirmesi. Ege Üniversitesi Tıp Fakültesi, Türk Klinik Biyokimya Dergisi. 2008; 6: 23-31.

24. Wang Y, Zhu J, DeLuca HF. Where is the vitamin D receptor? Arch Biochem Biophys. 2012 Jul 1;523(1):123-133.

25. Lee JH, et al. Vitamin D Deficiency- An Important,Common, and Easily Treatable Cardiovascular Risk Factor? J Am Coll Cardiol. 2008 Dec 9;52(24):1949-56.

26. Norman AW, Bouillon R. Vitamin D nutritional policy needs a vision for the future. Exp Biol Med. 2010;235(9):1034-45.

27. Moyad MA. Vitamin D: A Rapid Review. Urol Nurs. 2008;28(5):343-349.

28. International Meeting of Vitamin D Scientists Reveals Most Not Getting Enough to Maintain Health [Internet]. Erişim: http://newsroom.ucr.edu/1321. Erişim tarihi: 22.12.2017.

29. Kıldır V. D Vitamininin kardiyovasküler ve metabolik etkileri. Journal of Clinical and Experimental Investigations. 2013; 4 (3): 398-404

30. Cashman KD, et al. Vitamin D deficiency in Europe: pandemic? Am J Clin Nutr. 2016 Apr;103(4):1033-1044.

31. Türkiye'de D vitamini eksikliği var [Internet]. Erişim: http://aa.com.tr/tr/saglik/turkiyede-d-vitamini-eksikligi-var/669650. Erişim tarihi:23.12.2017.

32. Satman I, et al. Prevalence of Vitamin D Deficiency and Associated Factors in Turkey. The Endocrine Society. J Clin Endocrinol Metab 2011; 96:1911.

33. Yavuz DG. Osteoporoz ve Metabolik Kemik Hastalıkları Tanı ve Tedavi Kılavuzu [Internet]. Erişim:https://www.researchgate.net/publication/303404228_OSTEOPOROZ_ve_METABOLIK_KEMIK_HASTALIKLARI_TAN I_ve_TEDAVI_KILAVUZU. Erişim tarihi: 12.09.2018.

34. Lavie CJ, Lee JH, Milani RV. Vitamin D and Cardiovascular Disease Will It Live Up to its Hype? J Am Coll Cardiol. 2011 Oct 4;58(15):1547-1556.

35. Wacker M, Holick MF. Vitamin D-Effects on Skeletal and Extraskeletal Health and the Need for Supplementation. Nutrients. 2013 Jan; 5(1): 111-148.

36. Apperly FL. The relation of solar radiation to cancer mortality in North American. Cancer Res 1941;1:191-195.

37. Garland CF, Garland FC. Do sunlight and vitamin D reduce the likelihood of colon cancer? Int J Epidemiol. 1980 Sep;9(3):227-231.

38. Larsen ER, Mosekilde L, Foldspang A. Vitamin D and calcium supplementation prevents osteoporotic fractures in elderly community dwelling residents:a pragmatic population-based 3-year intervention study. J Bone Miner Res. 2004 Mar;19(3):370-378.

39. Ahonen $\mathrm{MH}$, et al. Prostate cancer risk and prediagnostic serum 25 -hydroxyvitamin D levels (Finland). Cancer Causes Control. 2000 Oct;11(9):847-852.

40. Bertone-Johnson ER, et al. Plasma 25-hydroxyvitamin D and 1,25- dihydroxyvitamin D and risk of breast cancer. Cancer Epidemiol Biomarkers Prev. 2005 Aug;14(8):1991-1997.

41. Garland CF, et al. Serum 25-hydroxyvitamin D and colon cancer: eightyear prospective study. Lancet. 1989 Nov 18;2(8673):1176-8. 
42. Garland CF, et al. Vitamin D for cancer prevention: global perspective. Ann Epidemiol. 2009 Jul;19(7):468-483.

43. Sözen T. D Hormonu: Güncel Gelişmeler, Hacettepe Tıp Dergisi. 2011; 42:14-27

44. Wu K, et al. A nested case control study of plasma 25 hydroxyvitamin D concentrations and risk of colorectal cancer. J Natl Cancer Inst. 2007 Jul 18;99(14):1120-1129.

45. Jenab $\mathrm{M}$, et al. Association between pre-diagnostic circulating vitamin $\mathrm{D}$ concentration and risk of colorectal cancer in European populations:a nested case-control study. BMJ. 2010 Jan 21;340:b5500.

46. Sofi NY, et al. Reproductive factors, nutritional status and serum 25(OH)D levels in women with breast cancer: A case control study. J Steroid Biochem Mol Biol. 2018 Jan;175:200-204.

47. Bauer SR, et al. Plasma vitamin D levels, menopause, and risk of breast cancer: dose-response meta-analysis of prospective studies. Medicine (Baltimore). 2013 May;92(3):123-131.

48. Chlebowski RT, et al. Calcium plus vitamin D supplementation and the risk of breast cancer. J Natl Cancer Inst. 2008 Nov 19;100(22):1581-1591.

49. Arem H, et al. Vitamin D metabolic pathway genes and pancreatic cancer risk. PLoS One. 2015 Mar 23;10(3):e0117574.

50. Barreto SG, Neale RE. Vitamin D and pancreatic cancer. Cancer Lett. 2015 Nov 1;368(1):1-6.

51. Huang JD, et al. Circulating 25-hydroxyvitamin D level and prognosis of lung cancer patients: A systematic reviewand meta-analysis. Bull Cancer. 2017 Jul - Aug;104(7-8):675-682.

52. Pandolfi F, et al. Immune Modulation by Vitamin D: Special Emphasis on Its Role in Prevention and Treatment of Cancer. Clin Ther. 2017 May;39(5):884-893. 